\title{
Effects of Organic Residues on Soil Properties and Sesame Water Use Efficiency
}

\author{
Paul Anguria ${ }^{1}$, George N. Chemining'wa ${ }^{2}$, Richard N. Onwonga ${ }^{3} \&$ Michael A. Ugen $^{1}$ \\ ${ }^{1}$ National Semi Arid Resources Research Institute (NaSARRI), Soroti, Uganda \\ ${ }^{2}$ Department of Plant Science and Crop Protection, University of Nairobi, Nairobi, Kenya \\ ${ }^{3}$ Department of Land Resource Management and Agricultural Technology, University of Nairobi, Nairobi, \\ Kenya
}

Correspondence: Paul Anguria, National Semi Arid Resources Research Institute, Serere, P.O. Box 56, Soroti, Uganda. E-mail: paulanguria@yahoo.com

Received: January 24, 2017

Accepted: March 15, 2017 Online Published: May 15, 2017

doi:10.5539/jas.v9n6p98

URL: https://doi.org/10.5539/jas.v9n6p98

\begin{abstract}
A study was conducted at the National Semi-Arid Resources Research Institute-Serere, Uganda for three seasons (2013 short rains, 2014 long rains and 2014 short rains) to investigate the effect of crop residues and animal manure on soil bulk density (SBD), soil moisture content (SMC) and water use efficiency (WUE) of sesame. The experiment was laid out in a randomized complete block design with three replications. The treatments comprised: control, 4 crop residues, 2 animal manures and combinations of 2 animal manures and 4 crop residues all applied at two rates of 3 and $6 \mathrm{t} / \mathrm{ha}$. Plots treated with $6 \mathrm{t} / \mathrm{ha}$ of millet husks produced the highest SMC $(37.46 \%)$ and lowest SBD $\left(1.1717 \mathrm{~g} / \mathrm{cm}^{3}\right)$ across seasons; while plots treated with $3 \mathrm{t} / \mathrm{ha}$ of millet husks produced the highest WUE of sesame $\left(9.92 \mathrm{~kg} \mathrm{ha}^{-1} \mathrm{~mm}^{-1}\right)$ across seasons compared with other crop residue and animal manure treatments applied singly. Soil moisture content was highest $(38.09 \%)$ and SBD lowest $(1.0520$ $\mathrm{g} / \mathrm{cm}^{3}$ ) across seasons in plots treated with $6 \mathrm{t} / \mathrm{ha}$ of poultry manure plus millet husks; while plots amended with $3 \mathrm{t} / \mathrm{ha}$ of poultry manure plus millet husks produced the highest WUE of sesame $\left(9.40 \mathrm{~g} / \mathrm{cm}^{3}\right)$ across seasons compared with other treatments. Crop residues influenced SMC and SBD in the order; millet husks $>$ cowpea husks $>$ sorghum husks $>$ groundnut shells. Crop residues affected WUE of sesame in the order; millet husks $>$ sorghum husks $>$ groundnut shells $>$ cowpea husks. This study has demonstrated that poultry manure plus millet husks have a potential to enhance WUE of sesame.
\end{abstract}

Keywords: crop residues, soil bulk density, soil moisture content, water use efficiency

\section{Introduction}

Sesame (Sesamum indicum L.) is cultivated in north eastern Uganda (NEU) as a food security and income crop, unfortunately its yields have greatly declined due to poorly distributed rain coupled with low soil water retention (FEWSNET, 2005). Yields as low as $400 \mathrm{~kg}$ /ha have been reported in farmers' fields compared with a potential yield of $2250 \mathrm{~kg} / \mathrm{ha}$ (Anyanga et al., 2003). Some areas in NEU receive annual rainfall of up to $1500 \mathrm{~mm}$ but poorly distributed (FEWSNET, 2010). Inadequate rains cause reduced availability of soil water for crop growth and conversion to biomass and yield (Herwaarden, 2001; Abbate et al., 2004). Low soil moisture impedes organic residue decomposition and this coupled with low plant biomass results in little organic matter accumulation (Ekaya, 2007). Consequently, the soils remain poor with low moisture retention contributing to persistently low crop yields. However, north eastern Uganda has large quantities of crop residues and animal manure that can be applied on soils to improve their soil physical properties and sesame productivity.

Crop residues and animal manure are a potential source of organic matter in soils. Essentially, the presence of organic matter in soils is responsible for improved chemical and physical properties of the soil through mineralization and gelation of soil particles. Consequently, organic matter influences soil stability and water infiltration which are a prerequisite for soil water storage (Brady et al., 2009). Soil organic matter indirectly affects some of the plant and soil aspects important in plant growth like soil bulk density, soil moisture content and crop water use efficiency (Weil et al., 2009). 
Soil bulk density (SBD) is an indicator of soil compaction and soil health. It affects infiltration, root penetration, available soil moisture capacity, soil porosity, plant nutrient availability, and soil microbial activity (Skousen, 2011). It is expressed as the weight of dry soil per unit of volume usually expressed in grams $/ \mathrm{cm}^{3}$ (Brady et al., 2002). Soil bulk density affects plant growth by influencing soil strength and soil porosity. Increase in SBD reduces soil strength and porosity and the reverse occurs when it decreases. Changes in SBD depict changes in soil structure due to the relationship that exists between SBD and total porosity. Therefore, soil bulk density can be used to monitor soil quality as an indicator of both soil structure and soil strength (Doran et al., 1994; Reichert., 2009). Fundamentally, SBD affects Soil Moisture Content (SMC) and its availability and accessibility to plants (Sato et al., 2015). Due to the relationship between SBD and soil porosity, it is possible to improve SMC by manipulating the level of organic matter in soil by applying organic matter rich amendments (Rivenshield et al., 2007).

Soil moisture content is an important soil aspect that is influenced by soil physical conditions like porosity (Tarboton, 2003). It can be expressed gravimetrically as weight of soil water per unit weight of dry soil (DeAngelis, 2007). The extent of rain water infiltration in the soil determines the level of available soil moisture at the root zone and this is dependent on soil porosity and SBD (Sato et al., 2015). Soils with high SBD values tend to be less porous and therefore store water for longer periods than soils with low SBD (Archer, 2006; Khalid et al., 2014). Soil moisture content is influenced by the force with which water is held in the soil referred to as tension and is measured in bars (Brady et al. 2002). Decrease in water content decreases soil water potential (Zou, 2001). Availability and the ease with which plants can access soil moisture at the root zone determine their efficiency in its use (Ebaid, 2007). The amount of organic matter in soil affects its ability to retain moisture and allow for infiltration (Sarwar et al., 2008; Yongxia et al., 2013). Therefore, applying soil amendments with high levels of organic matter would most likely improve SMC since it is directly affected by soil organic carbon which is a main component of soil organic matter (Parajuli, 2013). The extent of SMC influences crop WUE, optimum SMC results in optimum crop WUE (Hochman, 2009).

Crop water use efficiency, defined as the efficiency with which an individual crop converts water transpired to grain, is influenced indirectly by soil physical conditions (Doherty et al., 2010). Crop WUE is premised on; the soil's ability to absorb and store water, the ability of the crop to access water stored in the soil during the season, ability of the crop to convert absorbed water into biomass and ability of the crop to convert biomass into grain (Carvalho et al., 2016). The fact that the amount of organic matter in the soil affects SMC implies that increasing organic matter levels in the soil would most probably increase crop WUE (Fan et al., 2005). High contents of organic matter in crop residues and animal manure provides them with the potential to influence soil physical conditions and crop water use efficiency (Surekha et al., 2003). Consequently, incorporation of crop residues and animal manure in low fertility soils of north eastern Uganda has a potential to enhance crop production (Nakyagaba et al., 2005). However insufficient information exists regarding effect of the existing crop residues and animal manure on SMC, SBD and sesame productivity. Subsequently, a study was conducted to evaluate the effect of applying crop residues and animal manure on SMC, SBD and crop WUE of sesame.

\section{Materials and Methods}

\subsection{Description of Experimental Site}

\subsubsection{Weather Conditions at the Experimental Site}

This study was conducted at the National Semi-Arid Resources Research Institute (NaSARRI)-Serere, Uganda. NaSARRI is located at $0^{\circ} 32^{\prime} \mathrm{N}$ and $35^{\circ} 27^{\prime} \mathrm{E}$ at 1128 meters above sea level. The site experiences an average annual minimum temperature of $17.9^{\circ} \mathrm{C}$ and a maximum temperature of $29.4{ }^{\circ} \mathrm{C}$. It receives an average annual rainfall of $1000 \mathrm{~mm}$ with a bimodal distribution. The relative humidity ranges between $72 \%$ and $84 \%$. The months of January to February and June to July receive little precipitation. However, the months of March to May and August to November are generally wetter with significant precipitation (Figure 1). 


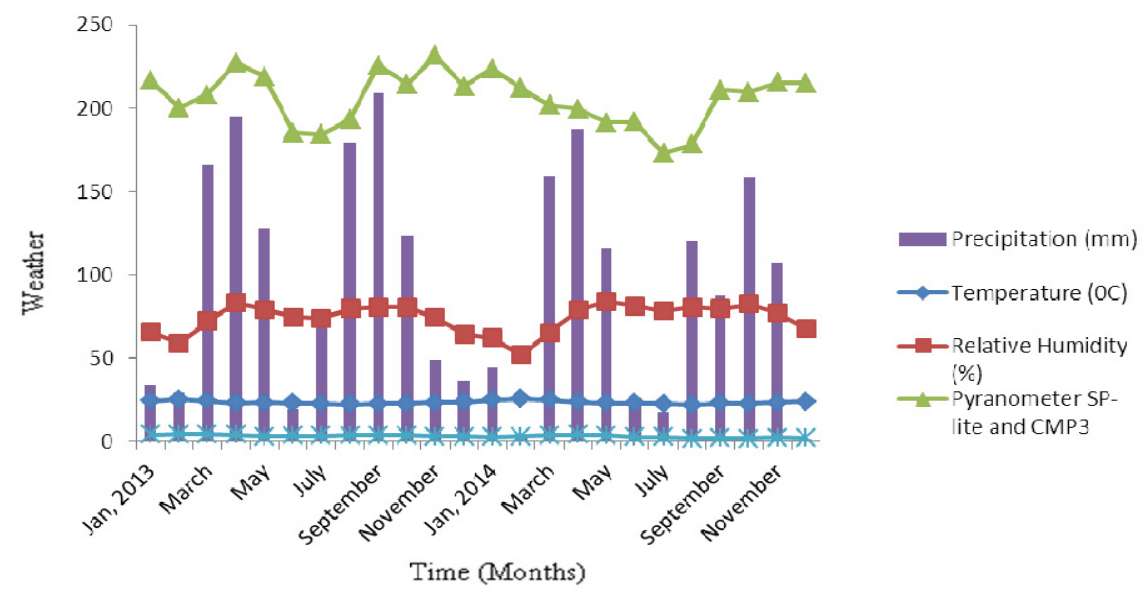

Figure 1. Meteorological data at the experimental site

\subsubsection{Soil Properties at the Experimental Site}

Soils at the experimental site are mainly sandy with low organic matter content and are classified as petric plinthosols, although they have traces of soils classified as gleysols and vertisols (Aniku, 2001). Chemical analyses of the soils at the experimental site revealed that they are predominantly sandy silt loams in texture with a $\mathrm{pH}$ ranging between 5.10 and 5.40. The low soil $\mathrm{pH}$ can be attributed to a low level of $\mathrm{Ca}(3.13 \mathrm{me} / 100 \mathrm{~g})$ compared with the critical value of $4 \mathrm{me} / 100 \mathrm{~g}$ and over use of chemicals over time. The amount of organic carbon is low; it ranges between 1.8 and $2.3 \%$ compared with the critical value of $6 \%$. These soils are also low in $\mathrm{P}(9.74 \mathrm{ppm})$ and $\mathrm{Na}(0.48 \mathrm{me} / 100 \mathrm{~g})$ compared with their critical values of $15 \mathrm{ppm}$ and $1.01 \mathrm{me} / 100 \mathrm{~g}$ respectively. However, these soils are quite high in $\mathrm{Mg}(0.71 \mathrm{me} / 100 \mathrm{~g})$ and $\mathrm{K}(0.67 \mathrm{me} / 100 \mathrm{~g})$ compared with their critical values of $0.50 \mathrm{me} / 100$ g and 0.20 me/100 g respectively (Table 1; Heckman., 1914; Mehlich., 1984; Lorry et al., 2003).

Table 1. Mean of soil physical and chemical properties at the experimental site

\begin{tabular}{lll}
\hline Soil property & Average values at the site & Critical values \\
\hline Soil $\mathrm{pH}$ & 5.37 & 5.50 \\
$\mathrm{~N}(\%)$ & 0.14 & 0.20 \\
Organic carbon $(\%)$ & 2.00 & 6.00 \\
Phosphorus $(\mathrm{PPM})$ & 9.74 & 15.0 \\
Potassium $(\mathrm{Me} / 100 \mathrm{~g})$ & 0.67 & 0.20 \\
Calcium $(\mathrm{Me} / 100 \mathrm{~g})$ & 3.13 & 4.00 \\
Magnesium $(\mathrm{Me} / 100 \mathrm{~g})$ & 0.71 & 0.50 \\
Sodium $(\mathrm{Me} / 100 \mathrm{~g})$ & 0.48 & 1.01 \\
Sand $(\%)$ & 50 & - \\
Clay $(\%)$ & 9 & - \\
Silt $(\%)$ & 41 & - \\
\hline
\end{tabular}

\subsection{Treatments}

Animal manure and crop residues were mixed in equal proportions of $1: 1 ; 1$ part of animal manure: 1 part of crop residue. Both crop residues and animal manure were analyzed for chemical elements before they were applied on experimental plots.

\subsubsection{Chemical Composition of Crop Residues and Animal Manure Used}

Organic carbon, $\mathrm{C} / \mathrm{N}$ ratio and nutrients in crop residues and animal manure occurred in the following ranges; $\mathrm{N}$ (1.80-4.44\%), Organic carbon (30.84-36.28\%), P (0.07-1.02\%), K (0.33-1.13\%), Ca $(0.11-1.24 \%), \mathrm{Mg}$ $(0.12-2.44 \%)$ and $\mathrm{C} / \mathrm{N}$ ratio $(8.13-11.59 \%)$. 


\subsection{Experimental Design and Crop Husbandry}

\subsubsection{Experimental Design}

The treatments (Table 2) were laid out in a randomized complete block design and replicated three times.

Table 2. Description of treatments

\begin{tabular}{|c|c|c|}
\hline Treatment & Treatment detail & Rate \\
\hline $\mathrm{T} 1$ & Control & 0 \\
\hline \multicolumn{3}{|c|}{ Animal manures } \\
\hline $\mathrm{T} 2$ & Poultry manure & $3 \mathrm{t} / \mathrm{ha}$ \\
\hline $\mathrm{T} 3$ & Poultry manure & $6 \mathrm{t} / \mathrm{ha}$ \\
\hline $\mathrm{T} 4$ & Cow manure & $3 \mathrm{t} / \mathrm{ha}$ \\
\hline T5 & Cow manure & $6 \mathrm{t} / \mathrm{ha}$ \\
\hline \multicolumn{3}{|c|}{ Crop residues } \\
\hline T6 & Millet husks & $3 \mathrm{t} / \mathrm{ha}$ \\
\hline $\mathrm{T} 7$ & Millet husks & $6 \mathrm{t} / \mathrm{ha}$ \\
\hline $\mathrm{T} 8$ & Sorghum husks & $3 \mathrm{t} / \mathrm{ha}$ \\
\hline T9 & Sorghum husks & $6 \mathrm{t} / \mathrm{ha}$ \\
\hline $\mathrm{T} 10$ & Cowpea husks & $3 \mathrm{t} / \mathrm{ha}$ \\
\hline T11 & Cowpea husks & $6 \mathrm{t} / \mathrm{ha}$ \\
\hline T12 & Groundnut shells & $3 \mathrm{t} / \mathrm{ha}$ \\
\hline $\mathrm{T} 13$ & Groundnut shells & $6 \mathrm{t} / \mathrm{ha}$ \\
\hline \multicolumn{3}{|c|}{ Poultry manure combined with crop residues } \\
\hline T14 & Poultry manure + millet husks & $3 \mathrm{t} / \mathrm{ha}$ \\
\hline $\mathrm{T} 15$ & Poultry manure + millet husks & $6 \mathrm{t} / \mathrm{ha}$ \\
\hline T16 & Poultry manure + sorghum husks & $3 \mathrm{t} / \mathrm{ha}$ \\
\hline $\mathrm{T} 17$ & Poultry manure + sorghum husks & $6 \mathrm{t} / \mathrm{ha}$ \\
\hline $\mathrm{T} 18$ & Poultry manure + cowpea husks & $3 \mathrm{t} / \mathrm{ha}$ \\
\hline T19 & Poultry manure + cowpea husks & $6 \mathrm{t} / \mathrm{ha}$ \\
\hline $\mathrm{T} 20$ & Poultry manure + groundnut shells & $3 \mathrm{t} / \mathrm{ha}$ \\
\hline $\mathrm{T} 21$ & Poultry manure + groundnut shells & $6 \mathrm{t} / \mathrm{ha}$ \\
\hline \multicolumn{3}{|c|}{ Cow manure combined with crop residues } \\
\hline $\mathrm{T} 22$ & Cow manure + millet husks & $3 \mathrm{t} / \mathrm{ha}$ \\
\hline $\mathrm{T} 23$ & Cow manure + millet husks & $6 \mathrm{t} / \mathrm{ha}$ \\
\hline $\mathrm{T} 24$ & Cow manure + sorghum husks & $3 \mathrm{t} / \mathrm{ha}$ \\
\hline $\mathrm{T} 25$ & Cow manure + sorghum husks & $6 \mathrm{t} / \mathrm{ha}$ \\
\hline $\mathrm{T} 26$ & Cow manure + cowpea husks & $3 \mathrm{t} / \mathrm{ha}$ \\
\hline $\mathrm{T} 27$ & Cow manure + cowpea husks & $6 \mathrm{t} / \mathrm{ha}$ \\
\hline $\mathrm{T} 28$ & Cow manure + groundnut shells & $3 \mathrm{t} / \mathrm{ha}$ \\
\hline $\mathrm{T} 29$ & Cow manure + groundnut shells & $6 \mathrm{t} / \mathrm{ha}$ \\
\hline
\end{tabular}

\subsubsection{Crop Husbandry}

Each experimental plot measured $4 \mathrm{~m} \times 4 \mathrm{~m}$. Sesim II Sesame crop variety was used in this study. It is highly branching with an average height of $100 \mathrm{~cm}$ and a maturity period of 90 days. Six seeds were planted per hill at inter and intra row spacing of $30 \mathrm{~cm}$ and $15 \mathrm{~cm}$ respectively. The crop was then thinned out to one plant per hill at three weeks after planting. The crop was hand-weeded three times before it was harvested.

\subsection{Data Collection}

\subsubsection{Soil Bulk Density}

Bulk density was measured using the core method (Blake \& Hartage, 1986). In this method, cylindrical soil core samplers of $8 \mathrm{~cm}$ height and $5 \mathrm{~cm}$ diameter were used for collection of samples. Soil cores were taken from different plots having different treatments. Soil bulk density was then calculated as follows: 


$$
\mathrm{SBD}\left(\mathrm{grams} / \mathrm{cm}^{3}\right)=\frac{\text { Mass of soil }}{\text { Volume of soil }}
$$

\subsubsection{Soil Moisture Content}

The gravimetric method was used to determine soil moisture content (DeAngelis, 2007). Soil samples measuring 100-200 g were collected from each of the experimental plot. The soil samples were placed in an air tight container of known weight (tare) and then weighed. The sample were then put in an oven and heated at $105^{\circ} \mathrm{C}$ for 24 hours. The moisture content was then calculated as the difference between the weights of the wet and oven dried samples and then expressed as a percentage of the original soil sample as shown below:

Moisture content: (Weight of wet soil-Weight of dry soil) = weight of water,

$$
\text { Soil moisture content }=\frac{\text { Weight of water }}{\text { Weight of wet soil }} \times 100
$$

\subsubsection{Water Use Efficiency of Sesame}

Water use efficiency of sesame was determined for each treatment as described by Katerji et al. (2014):

$$
\text { WUE }=\frac{\text { Crop yield (sesame yield) in } \mathrm{kg} / \mathrm{ha} \text { at harvest }}{\text { Estimated water used by the crop during the growing season }\left(\mathrm{mm}^{3}\right)}
$$

Sesame crop yield was determined by harvesting the crop at physiological maturity from an area of $4 \mathrm{~m}^{2}$ in each experimental plot. This was used to calculate crop yield in $\mathrm{kg} / \mathrm{ha}$. Estimated water used by the crop during the growing season was determined by measuring the initial amount of water stored in the soil at the start of the crop growing season and the amount of rainfall during the crop growing period; this is equivalent to amount of water supplied to the crop during growing period. The amount of water stored in the soil at the end of the crop growing season was also measured. The difference between the initial soil water and soil water at the end of growing season plus the rainfall was calculated to obtain crop water use. WUE was then calculated using the above equation where measured water used by the crop was equivalent to water lost through evapo-transpiration.

\subsection{Data Analysis}

Data on SBD, SMC and WUE of sesame were subjected to analysis of variance (ANOVA) using Genstat statistical package; where the ANOVA gave significant $\mathrm{F}$ values, means were compared using the least significant difference (LSD) test at $\mathrm{P} \leq 0.05$.

\section{Results}

\subsection{Soil Moisture Content (SMC) as Influenced by Crop Residues, Animal Manures and Their Combinations}

Application of crop residues and animal manure singly or in combination significantly $(\mathrm{P}<0.05)$ increased SMC across the seasons (Tables $3 \mathrm{a}, 3 \mathrm{~b}$ and $3 \mathrm{c}$ ). Plots treated with $6 \mathrm{t} / \mathrm{ha}$ of millet husks produced significantly $(\mathrm{P}<$ 0.05 ) higher SMC (29.18\%, 37.46\% and 33.49\%) in 2013 SR, 2014 LR and 2014 SR respectively compared to other crop residue treatments (Table 3a). Plots treated with $6 \mathrm{t} / \mathrm{ha}$ of poultry manure produced significantly $(\mathrm{P}<$ 0.05) higher SMC $(29.20 \%, 36.13 \%$ and $30.61 \%$ in 2013 SR, 2014 LR and 2014 SR respectively compared to other animal manure treatments (Table 3a). Incorporation of $6 \mathrm{t} /$ ha of poultry manure combined with millet husks into soil produced significantly $(\mathrm{P}<0.05)$ higher SMC $(34.62 \%, 38.09 \%$ and $33.01 \%$ in 2013 SR, 2014 LR and 2014 SR respectively compared to poultry manure plus other crop residue treatments (Table 3b). Combined application of $6 \mathrm{t} / \mathrm{ha}$ of cow manure with millet husks significantly $(\mathrm{P}<0.05)$ produced higher SMC $(34.06 \%)$, (49.73\%) and (40.53\%) in 2013 SR, 2014 LR and 2014 SR respectively compared with cow manure combined with other crop residues (Table 3c). Soil moisture content was higher in plots treated with animal manure combined with crop residues than either crop residues or animal manure applied singly. While plots treated with crop residue treatments showed higher SMC than plots treated with animal manure treatments. Overall, poultry manure plus millet husks produced the highest SMC compared to all treatments. The crop residue treatments influenced SMC in the order; cowpea husks $>$ millet husks $>$ groundnut shells $>$ sorghum husks.

\subsection{Soil Bulk Density (SBD) as Influenced by Crop Residues, Animal Manures and Their Combinations}

Incorporation of crop residues, animal manure combined with crop residues on the soil significantly $(\mathrm{P}<0.05)$ reduced the SBD compared to the control across the seasons (Tables 3a, 3b, and 3c). Application of $6 \mathrm{t} / \mathrm{ha}$ of millet husks produced significantly $(\mathrm{P}<0.05)$ lower SBD $\left(1.48 \mathrm{~g} / \mathrm{cm}^{3}, 1.17 \mathrm{~g} / \mathrm{cm}^{3}\right.$ and $1.37 \mathrm{~g} / \mathrm{cm}^{3}$ in $2013 \mathrm{SR}$, 2014 LR and 2014 SR respectively) compared with other crop residue treatments (Table 3a). Plots treated with 6 $\mathrm{t} / \mathrm{ha}$ of poultry manure produced significantly $(\mathrm{P}<0.05)$ lower $\operatorname{SBD}\left(1.45 \mathrm{~g} / \mathrm{cm}^{3}\right),\left(1.27 \mathrm{~g} / \mathrm{cm}^{3}\right)$ and $\left(1.36 \mathrm{~g} / \mathrm{cm}^{3}\right)$ in 2013 SR, 2014 LR and 2014 SR respectively compared with other animal manure treatments and the control 
(Table 3a). Plots amended with $6 \mathrm{t} / \mathrm{ha}$ of poultry manure combined with millet husks produced significantly $(\mathrm{P}<$ $0.05)$ lower SBD $\left(1.43 \mathrm{~g} / \mathrm{cm}^{3}\right),\left(1.25 \mathrm{~g} / \mathrm{cm}^{3}\right)$ and $\left(1.05 \mathrm{~g} / \mathrm{cm}^{3}\right)$ in $2013 \mathrm{SR}, 2014$ LR and 2014 SR respectively compared with poultry manure combined with other crop residue treatments (Table $3 b$ ). Plots amended with 6 $\mathrm{t} / \mathrm{ha}$ of cow manure plus millet husks significantly $(\mathrm{P}<0.05)$ produced the lowest $\operatorname{SBD}\left(1.32 \mathrm{~g} / \mathrm{cm}^{3}\right),\left(1.22 \mathrm{~g} / \mathrm{cm}^{3}\right)$ and $\left(1.32 \mathrm{~g} / \mathrm{cm}^{3}\right)$ in $2013 \mathrm{SR}, 2014 \mathrm{LR}$ and $2014 \mathrm{SR}$ respectively compared with cow manure combined with other crop residue treatments (Table 3c). Soil bulk density was lower in plots treated with animal manure plus crop residues than plots treated with either crop residues or animal manure alone. Plots amended with animal manure produced lower SBD than plots treated with crop residues. Crop residues influenced SBD in the order; millet husks $>$ cowpea husks $>$ sorghum husks $>$ groundnut shells. Poultry manure combined with millet husks produced the lowest SBD compared to all treatments.

3.3 Water Use Efficiency (WUE) of Sesame as Influenced by Crop Residues, Animal Manures and Their Combinations

Among crop residues, only plots treated with $3 \mathrm{t} / \mathrm{ha}$ of millet husks produced significantly $(\mathrm{P}<0.05)$ higher WUE of sesame $\left(9.40 \mathrm{~kg} \mathrm{ha}^{-1} \mathrm{~mm}^{-1}\right.$, and $7.61 \mathrm{~kg} \mathrm{ha}^{-1} \mathrm{~mm}^{-1}$ in $2013 \mathrm{SR}$ and $2014 \mathrm{SR}$ respectively) compared to the control (Table 3a). Application of animal manure did not significantly $(\mathrm{P}<0.05)$ affect WUE of sesame across the seasons (Table 3a). Plots amended with $3 \mathrm{t} / \mathrm{ha}$ of poultry manure combined with millet husks produced significantly $(\mathrm{P}<0.05)$ higher WUE of sesame $\left(9.92 \mathrm{~kg} \mathrm{ha}^{-1} \mathrm{~mm}^{-1}\right)$ and $\left(7.91 \mathrm{~kg} \mathrm{ha}^{-1} \mathrm{~mm}^{-1}\right)$ in $2013 \mathrm{SR}$ and 2014 SR respectively compared to the control (Table $3 \mathrm{~b}$ ). Whereas plots treated with poultry manure plus cowpea husks produced significantly $(\mathrm{P}<0.05$ ) higher WUE of sesame only in 2014 SR (Table 3b). Cow manure combined with crop residues did not significantly $(\mathrm{P}<0.05)$ affect WUE of sesame across seasons (Table $3 \mathrm{c})$.

Table 3a. Soil physical properties as influenced by crop residues and animal manure

\begin{tabular}{|c|c|c|c|c|c|c|c|c|c|}
\hline \multirow[t]{2}{*}{ Treatments } & \multicolumn{3}{|c|}{ Soil moisture content $(\%)$} & \multicolumn{3}{|c|}{ Soil Bulk Density $\left(\mathrm{gcm}^{-3}\right)$} & \multicolumn{3}{|c|}{$\begin{array}{c}\text { Crop water use efficiency } \\
\left(\mathrm{kg} \mathrm{ha}^{-1} \mathbf{m m}^{-1}\right)\end{array}$} \\
\hline & 2013 SR & 2014 LR & 2014 SR & 2013 SR & 2014 LR & 2014 SR & 2013 SR & 2014 LR & 2014 SR \\
\hline Control & 22.92 & 21.09 & 23.87 & 1.63 & 1.59 & 1.68 & 5.58 & 5.01 & 4.90 \\
\hline \multicolumn{10}{|l|}{ Crop residues } \\
\hline Millet (3 t/ha) & 25.54 & 31.09 & 30.14 & 1.50 & 1.28 & 1.39 & 9.40 & 7.22 & 7.61 \\
\hline Millet (6 t/ha) & 29.18 & 37.46 & 33.49 & 1.48 & 1.17 & 1.37 & 7.54 & 6.04 & 6.57 \\
\hline Sorghum (3t/ha) & 26.80 & 30.04 & 28.42 & 1.54 & 1.30 & 1.39 & 7.83 & 4.56 & 3.55 \\
\hline Sorghum (6 t/ha) & 27.50 & 25.18 & 26.34 & 1.48 & 1.26 & 1.40 & 9.16 & 5.55 & 4.15 \\
\hline Cowpea (3 t/ha) & 25.58 & 33.52 & 29.83 & 1.58 & 1.28 & 1.42 & 6.13 & 3.85 & 2.52 \\
\hline Cowpea (6 t/ha) & 26.14 & 34.40 & 31.80 & 1.56 & 1.19 & 1.39 & 7.29 & 6.66 & 4.05 \\
\hline Groundnuts (3 t/ha) & 25.05 & 27.07 & 26.06 & 1.54 & 1.29 & 1.42 & 6.97 & 5.05 & 3.70 \\
\hline Groundnuts (6 t/ha) & 28.02 & 31.90 & 29.96 & 1.54 & 1.28 & 1.41 & 7.44 & 4.37 & 2.85 \\
\hline \multicolumn{10}{|l|}{ Animal manure } \\
\hline Poultry (3 t/ha) & 25.58 & 29.67 & 27.63 & 1.49 & 1.28 & 1.39 & 8.78 & 9.67 & 5.62 \\
\hline Poultry (6 t/ha) & 29.20 & 36.13 & 30.61 & 1.45 & 1.27 & 1.38 & 7.65 & 9.63 & 4.01 \\
\hline Cow $(3 \mathrm{t} / \mathrm{ha})$ & 25.08 & 20.91 & 25.06 & 1.52 & 1.30 & 1.40 & 8.75 & 7.16 & 2.48 \\
\hline Cow (6 t/ha) & 29.06 & 31.83 & 30.45 & 1.50 & 1.28 & 1.38 & 6.46 & 7.36 & 4.10 \\
\hline P-Value & 0.001 & 0.001 & 0.003 & 0.320 & 0.001 & 0.034 & 0.014 & 0.07 & 0.002 \\
\hline LSD (5\%) & 11.41 & 14.28 & 7.85 & NS & 0.14 & 0.61 & 3.81 & NS & 2.62 \\
\hline
\end{tabular}

Note. $\mathrm{LR}=$ long rains and $\mathrm{SR}=$ short rains. 
Table $3 \mathrm{~b}$. Soil physical properties as influenced by a combination of poultry manure with crop residues

\begin{tabular}{|c|c|c|c|c|c|c|c|c|c|}
\hline \multirow[t]{2}{*}{ Treatments } & \multicolumn{3}{|c|}{ Soil moisture content (\%) } & \multicolumn{3}{|c|}{ Soil Bulk Density $\left(\mathrm{g} / \mathrm{cm}^{3}\right)$} & \multicolumn{3}{|c|}{$\begin{array}{l}\text { Crop water use efficiency } \\
\left(\mathrm{kg} \mathrm{ha}^{-1} \mathrm{~mm}^{-1}\right)\end{array}$} \\
\hline & 2013 SR & 2014 LR & 2014 SR & 2013 SR & 2014 LR & 2014 SR & 2013 SR & 2014 LR & 2014 SR \\
\hline Control & 22.92 & 21.09 & 23.87 & 1.63 & 1.59 & 1.68 & 5.58 & 5.01 & 4.90 \\
\hline \multicolumn{10}{|c|}{ Poultry manure + crop residues } \\
\hline PM + Millet (3 t/ha) & 23.57 & 34.95 & 30.78 & 1.46 & 1.27 & 1.37 & 9.92 & 9.17 & 7.91 \\
\hline PM + Millet (6 t/ha) & 34.62 & 38.09 & 33.01 & 1.43 & 1.25 & 1.05 & 8.45 & 9.00 & 5.63 \\
\hline PM + Sorghum (3t/ha) & 24.00 & 28.48 & 27.46 & 1.56 & 1.27 & 1.41 & 8.11 & 7.88 & 5.27 \\
\hline $\mathrm{PM}+\operatorname{Sorghum}(6 \mathrm{t} / \mathrm{ha})$ & 26.60 & 31.39 & 30.15 & 1.48 & 1.25 & 1.39 & 8.48 & 8.53 & 5.37 \\
\hline PM + Cowpea $(3 \mathrm{t} / \mathrm{ha})$ & 23.14 & 31.82 & 28.48 & 1.50 & 1.28 & 1.37 & 8.39 & 7.54 & 7.53 \\
\hline PM + Cowpea $(6 \mathrm{t} / \mathrm{ha})$ & 31.40 & 36.29 & 32.54 & 1.46 & 1.28 & 1.06 & 8.66 & 8.32 & 6.51 \\
\hline PM + Groundnuts $(3 \mathrm{t} / \mathrm{ha})$ & 23.44 & 24.95 & 26.56 & 1.57 & 1.28 & 1.42 & 6.27 & 6.18 & 5.45 \\
\hline PM + Groundnuts $(6 \mathrm{t} / \mathrm{ha})$ & 26.98 & 29.20 & 30.30 & 1.54 & 1.27 & 1.41 & 6.96 & 8.47 & 4.97 \\
\hline P-Value & 0.001 & 0.001 & 0.003 & 0.320 & 0.001 & 0.034 & 0.014 & 0.07 & 0.002 \\
\hline LSD (5\%) & 11.41 & 4.28 & 7.85 & NS & 0.14 & 0.61 & 3.81 & NS & 2.62 \\
\hline
\end{tabular}

Note. $\mathrm{PM}=$ poultry manure, $\mathrm{LR}=$ long rains and $\mathrm{SR}=$ short rains.

Table 3c. Soil physical properties as influenced by a combination of cow manure with crop residues

\begin{tabular}{|c|c|c|c|c|c|c|c|c|c|}
\hline \multirow[t]{2}{*}{ Treatments } & \multicolumn{3}{|c|}{ Soil moisture content (\%) } & \multicolumn{3}{|c|}{ Soil Bulk Density $\left(\mathrm{g} / \mathrm{cm}^{3}\right)$} & \multicolumn{3}{|c|}{$\begin{array}{l}\text { Crop water use efficiency } \\
\left(\mathrm{kg} \mathrm{ha}^{-1} \mathbf{m m}^{-1}\right)\end{array}$} \\
\hline & 2013 SR & 2014 LR & 2014 SR & 2013 SR & 2014 LR & 2014 SR & 2013 SR & 2014 LR & $2014 \mathrm{SR}$ \\
\hline Control & 22.92 & 21.09 & 23.87 & 1.63 & 1.59 & 1.68 & 5.58 & 5.01 & 4.90 \\
\hline \multicolumn{10}{|c|}{ Cow manure + crop residues } \\
\hline $\mathrm{CM}+\operatorname{Millet}(3 \mathrm{t} / \mathrm{ha})$ & 31.32 & 35.54 & 31.30 & 1.41 & 1.27 & 1.40 & 8.25 & 7.94 & 4.96 \\
\hline $\mathrm{CM}+\operatorname{Millet}(6 \mathrm{t} / \mathrm{ha})$ & 34.06 & 49.73 & 40.53 & 1.32 & 1.22 & 1.32 & 9.40 & 9.71 & 5.58 \\
\hline $\mathrm{CM}+\operatorname{Sorghum}(3 \mathrm{t} / \mathrm{ha})$ & 24.08 & 25.04 & 26.32 & 1.52 & 1.30 & 1.58 & 6.59 & 9.14 & 4.98 \\
\hline $\mathrm{CM}+\operatorname{Sorghum}(6 \mathrm{t} / \mathrm{ha})$ & 30.52 & 31.30 & 27.33 & 1.53 & 1.27 & 1.37 & 9.02 & 7.97 & 5.23 \\
\hline $\mathrm{CM}+$ Cowpea $(3 \mathrm{t} / \mathrm{ha})$ & 26.58 & 32.06 & 28.85 & 1.44 & 1.29 & 1.41 & 8.81 & 7.56 & 4.98 \\
\hline $\mathrm{CM}+$ Cowpea $(6 \mathrm{t} / \mathrm{ha})$ & 31.96 & 37.82 & 34.89 & 1.46 & 1.25 & 1.36 & 9.14 & 9.91 & 5.42 \\
\hline $\mathrm{CM}+\mathrm{G}$. nuts $(3 \mathrm{t} / \mathrm{ha})$ & 23.36 & 24.94 & 30.76 & 1.51 & 1.45 & 1.37 & 6.23 & 5.09 & 4.97 \\
\hline $\mathrm{CM}+$ G.nuts $(6 \mathrm{t} / \mathrm{ha})$ & 27.59 & 33.61 & 28.85 & 1.53 & 1.28 & 1.40 & 6.56 & 9.61 & 5.08 \\
\hline P-Value & 0.001 & 0.001 & 0.003 & 0.320 & 0.001 & 0.034 & 0.014 & 0.07 & 0.002 \\
\hline LSD (5\%) & 11.41 & 14.28 & 7.85 & NS & 0.14 & 0.61 & 3.81 & NS & 2.62 \\
\hline
\end{tabular}

Note. $\mathrm{CM}=$ cow manure, G.nuts $=$ groundnut, $\mathrm{LR}=$ long rains and $\mathrm{SR}=$ short rains.

\section{Discussion}

4.1 Soil Water Content (SMC), Soil Bulk Density (SBD) and Crop Water Use Efficiency (WUE) of Sesame as Influenced by Crop Residues, Animal Manure and Their Combinations

Significant increases in soil moisture content (SMC) and water use efficiency (WUE) of sesame coupled with a significant reduction in soil bulk density (SBD) in soils amended with crop residues and animal manure is attributable to organic matter added to the soil. Increase in organic matter content could have improved soil pore space formation and aggregate stability, which subsequently improved water infiltration causing increased soil water storage hence, increased SMC. Consequently, increase in pore space reduced SBD by reducing soil mass and increasing soil volume. High SMC coupled with low SBD could have enabled the sesame crop to access adequate moisture and nutrients resulting in increased WUE. (Ebaid et al., 2007; Sarwar et al., 2008; Yinguang et al., 2015) similarly found that incorporation of organic residues on soil, increased SMC and but reduced SBD. This was attributed to increased pore space formed due to increased organic matter content. The most significant increase and reduction of SMC and SBD respectively due to application of $6 \mathrm{t} / \mathrm{ha}$ of millet husks on soil compared to other crop residues across seasons, could be attributed to difference in organic matter and organic carbon contents in the different crop residues. Millet husks could have added large quantities of organic matter 
and soil carbon to the soil that may have improved soil physical conditions that caused an increase in SMC and reduction in SBD. Significantly high WUE of sesame due to application of $3 \mathrm{t} / \mathrm{ha}$ of millet husks compared with other crop residues could be attributable to difference in their nutrient and organic matter contents. It is most likely that $3 \mathrm{t} / \mathrm{ha}$ of millet husks added optimum quantities of organic matter and plant nutrients $(\mathrm{N}, \mathrm{P}$ and $\mathrm{K})$ in to soil compared to other crop residues. Consequently, this may have provided optimum SMC and SBD that improved sesame efficiency in extracting and using soil water and nutrients resulting in increased high WUE. This consistent with Mohandoss (2001) and Ebaid et al. (2007) similarly obtained increased sesame yields and WUE due to application of $3 \mathrm{t} / \mathrm{ha}$ and $9 \mathrm{t} / \mathrm{ha}$ of rice husks respectively. Both cases were attributed to high amounts of organic matter and major plant nutrients in rice husks that could have improved soil physical conditions and nutrient supply. The most significant increase and reduction of SMC and SBD respectively due to application of $6 \mathrm{t} / \mathrm{ha}$ of poultry manure could be attributed to difference in organic matter and organic carbon contents. Poultry manure applied at a higher rate $(6 \mathrm{t} / \mathrm{ha})$ could have added large quantities of organic matter and organic carbon into the soil compared to cow manure (Moral et al., 2005) and this could have been responsible for significantly increased SMC and reduced SBD due to poultry manure compared to cow manure (Ewulo et al., 2008; Agbede et al., 2008; Khalidl et al., 2014)

Significant increase in SMC and reduction of SBD due to application of $6 \mathrm{t} / \mathrm{ha}$ of either poultry manure or cow manure combined with millet husks is most likely due to high content of organic matter in millet husks compared to other crop residues combined with either poultry manure or cow manure. Therefore application of either poultry manure or cow manure combined with millet husks at a higher rate $(6 \mathrm{t} / \mathrm{ha})$ could have added large amounts of organic matter to the soil that promoted pore space formation and subsequent reduction in SBD and increase in SMC. Quansah (2010) similarly reported that application of poultry manure in combination with household waste onto the soil significantly increased its moisture retention due to added organic matter into the soil. Liu et al. (2013) and Tilahun et al. (2013) similarly found that incorporation farm yard manure into soil significantly reduced SBD and yet at the same time significantly increased SMC due to large amounts of organic matter and organic carbon added on the soil.

The highest significant increase of WUE of sesame due to application of $3 \mathrm{t} / \mathrm{ha}$ of poultry manure plus millet husks and 6 t/ha of cow manure plus millet husks could be due to optimum amount of organic matter and nutrients $(\mathrm{N}, \mathrm{P}$ and $\mathrm{K})$ added to the soil by the two treatments compared with other combinations of animal manure with other crop residues. Consequently, soil physical conditions could have improved that ensured efficient extraction and use of moisture and nutrients by sesame resulting in its high WUE. Zhong et al. (2014) similarly found that increased application of organic residues with high nitrogen content on wheat significantly increased its WUE.

Crop residues influenced SMC in the order; millet husks $>$ cowpea husks $>$ groundnut shells $>$ sorghum husks. Soil bulk density was influenced by crop residues in the order; millet husks $>$ cowpea husks $>$ sorghum husks $>$ groundnut shells. Lastly, crop residues influenced WUE of sesame in the order; millet husks $>$ sorghum husks $>$ groundnut shells $>$ cowpea husks. Millet husks were superior to other crop residues in influencing SBD, SMC and WUE of sesame. Consequently, millet husks demonstrated their potential for use by small scale sesame farmers and this supported by their abundance among sesame farmers. Overall, crop residues combined with animal manure were superior in affecting SMC, SBD and WUE of sesame compared to either animal manure alone or crop residues alone.

\section{Conclusion}

Soil moisture content and SBD were highest and lowest respectively at $6 \mathrm{t} / \mathrm{ha}$ of poultry manure combined with millet husks; while WUE of sesame was highest at $3 \mathrm{t} / \mathrm{ha}$ of poultry manure plus millet husks. Application of 3 t/ha of poultry manure plus millet husks appears to be the most ideal for increasing WUE of sesame and should therefore be recommended. This study has therefore demonstrated that poultry manure combined with millet husks has a potential to improve sesame growth and yields.

\section{References}

Agbede, T. M., Ojeniyi, S. O., \& Adeyemo, A. J. (2008). Effect of Poultry Manure on Soil Physical and Chemical Properties, Growth and Grain Yield of Sorghum in Southwest, Nigeria. Am.-Eurasian Journal of Sustainable Agriculture, 2(1), 72-77.

Al Jassar, H. K., \& Rao, K. S. (2015). Assessment of soil moisture through field measurements and AMSR-E remote sensing data analysis over Kuwait desert. Kuwait Journal of Science, 42(2). 
Angela, R., \& Bassuk, N. L. (2007). Using Organic Amendments to Decrease Bulk Density and Increase Macroporosity in Compacted Soils. Arboriculture and Urban Forestry, 33(2), 140-146.

Aniku, J. R. F. (2001). Soil classification and pedology. Kampala, Uganda: Fountain Publishers.

Blake, G. R., \& Hartge, K. H. (1986). Bulk density. In A. Klute (Ed.), Methods of Soil Analysis (Part 1): Physical and Mineralogical Methods (2nd ed., pp. 363-375). SSSA Book Series 5, Madison Wisconsin, USA.

Carvalho, N. J., Oliveira., D. F. D., Neto, D. H. D., Felix, L. F., Guerra, J. G. M., \& Salvador, C. A. (2016). Yield, water use efficiency, and yield response factor in carrot crop under different irrigation depths. Ciência Rural, 46(7), 1145-1150. http://dx.doi.org/10.1590/0103-8478cr20150363

DeAngelis, K. M. (2007). Measurement of soil moisture content by gravimetric method Soil moisture content. College of Natural Resources, UC.

DeLong, C., Skousen, J., \& Pena-Yewtukhiw, E. (2011). Soil Science Society of America. 5585 Guilford Rd., Madison, WI, USA. https://doi.org/10.2136/sssaj2011.0380

Doherty, A., Sadras, V. O., Rodriguez, D., \& Potgieter, A. (2010). Quantification of wheat water-use efficiency at the shire-level in Australia. Crop and Pasture Science, 61(1), 1-11. https://doi.org/10.1071/CP09157

Doran, J. W., \& Parkin, T. B. (1994). Defining and assessing soil quality (pp. 3-21). https://doi.org/10.2136/ sssaspecpub35.c1

Ebaid, A. (2007). Exact solitary wave solutions for some nonlinear evolution equations via Exp-function method. Physics Letters A, 365(3), 213-219. https://doi.org/10.1016/j.physleta.2007.01.009

Ewulo, B. S., Ojeniyi, S. O. L., \& Akanni, D. A. (2008). Effect of poultry manure on selected soil physical andchemical properties, growth, yield and nutrient status of tomato. African Journal of Agricultural Research, 3(9), 612-616.

Fan, T., Stewart, B. A., Yong, W., Junjie, L., \& Guangye, Z. (2005). Long-term fertilization effects on grain yield, water-use efficiency and soil fertility in the dryland of Loess Plateau in China. Agriculture, Ecosystems \& Environment, 106(4), 313-329. https://doi.org/10.1016/j.agee.2004.09.003

Heckman, J. R. (1914). Soil Fertility Test Interpretation Phosphorus, Potassium, Magnesium, and Calcium. Extension Specialist in Soil Fertility. The state University of New Jersey. Retrieved from http://www.rce.rutgers.edu

Hochman, Z., Holzworth, D., \& Hunt, J. R. (2009). Potential to improve on-farm wheat yield and WUE in Australia. Crop and Pasture Science, 60(8), 708-716. https://doi.org/10.1071/CP09064

John, L., \& Peter, S. (2003). Soil Specific Phosphorus and Potassium Recommendations-Critical Values. Department of Agronomy, University of Missouri.

Jose, M. R., Luis Eduardo, A. S. S., Dalvan, J. R., Rainer, H., \& Inge, H. (2009). Reference bulk density and critical degree-of-compactness for no-till crop production in subtropical highly weathered soils.

Katerji, N. \& Mastrorilli, M. (2014). Water Use Efficiency of Cultivated Crops. John Wiley and Sons Ltd., Chichester. https://doi.org/10.1002/9780470015902.a0025268

Khalid, A. A., Tuffour, H. O., Bonsu, M., \& Parker, B. Q. (2014). The effects of poultry manure and NPK fertilizer on physical properties of a sandy soil in Ghana. International Journal of Scientific Research in Agricultural Sciences, 1(1), 1-5. https://doi.org/10.12983/ijsras-2014-p0001-0005

Liu, E., Yan, C., Mei, X., Zhang, Y., \& Fan, T. (2013). Long term effect of Manure and Fertilizer on soil organic pools in Dryland Farming in North West China. PLoS ONE, 8(2), e56536. https://doi.org/10.1371/ journal.pone.0056536.

Marcelo, G. W., María, C. S., \& Octavio, P. C. (2013). Critical bulk density for a Mollisol and a Vertisol using least limiting water range: Effect on early wheat growth. Retrieved from http://www.elsevier.com/ locate/geoderma

Mehlich, A. (1984). Mehlich-3 soil test extractant: A modification of Mehlich-2 extractant. Commun. Soil Sci. Plant Anal., 15(12), 1409-1416. https://doi.org/10.1080/00103628409367568

Michel, K. S., Herdjania, V. L., Pedro, D. O., \& Sueli, R. (2015). Critical soil bulk density for soybean growth in Oxisols. Agrophys, 29, 441-447. https://doi.org/10.1515/intag-2015-0050 
Mohandoss, M. (2001). Effect of soil incorporation of paddy rice husk on the growth and yield parameters of sesame and on soil physico-chemical characteristics. Journal Sesame and Safflower Newsletter, 16, 60-61.

Moral, R., Moreno-Caselles, J., Perez-Murcia, M. D., Perez-Espinosa, A., Rufete, B., \& Paredes, C. (2005). Characterisation of the organic matter pool in maures. Biores. Technol., 96, 153-158. https://doi.org/10.1016/j.biortech.2004.05.003

Nakyagaba, N. W., Ssekabembe, C. K., \& Osiru, D. S. O. (2005). An overview of the agronomic constraints to simsim production in Uganda. African Crop Science Conference Proceedings, 7, 1221-1228.

Shukla, M. K., Lal, R., \& Ebinger, M. (2006). Determinig soil quality indicators by factor analysis. Soil and Tillage Research, 87(2), 194-204. https://doi.org/10.1016/j.still.2005.03.011

Surekha, K., Kumari, A. P., Reddy, M. N., Satyanarayana, K., \& Cruz, P. S. (2003). Crop residue management to sustain soil fertility and irrigated rice yields. Nutrient Cycling in Agroecosystems, 67(2), 145-154. https://doi.org/10.1023/A:1025543810663

Tarboton, D. G. (2003). Rainfall-Runoff Processes. Utah State University: Logan, UT, USA.

Tilahun, T., Nigussie, D., Wondimu, B., \& Setegn, G. (2013). Effects of Farmyard Manure and Inorganic Fertilizer Application on Soil Physico-Chemical Properties and Nutrient Balance in Rain-Fed Lowland Rice Ecosystem. American Journal of Plant Sciences, 4, 309-316. https://doi.org/10.4236/ajps.2013.42041

Weil, R. R. (2002). Soil and Environmental Quality: A Course for Non-Majors (link is external). Journal of Natural Resource Life Sciences Education, 31, 117-122.

Yinguang, S., Xining, Z., Shu, L. Z., \& Pute, W. (2015). The Effects of Long-term Fertiliser Applications on Soil Organic Carbon and Hydraulic Properties of a Loess Soil in China: Fertiliser Applications and Impacts on SOC and Hydraulic Properties. Retrieved from https://www.researchgate.net/researcher/78755558

Zou, C., Penfold, C., Sands, R., Misra, R. K., \& Hudson, I. (2001). Effects of soil air-filled porosity, soil matric potential and soil strength on primary root growth of radiata pine seedlings. Plant and Soil, 236(1), 105-115. https://doi.org/10.1023/A:1011994615014

\section{Copyrights}

Copyright for this article is retained by the author(s), with first publication rights granted to the journal.

This is an open-access article distributed under the terms and conditions of the Creative Commons Attribution license (http://creativecommons.org/licenses/by/4.0/). 